\title{
Dampak Negatif Academic Procrastination terhadap Rendahnya Tingkat Kelulusan Mahasiswa Universitas Borneo Tarakan
}

\author{
Tri Cahyono \\ Jurusan Bimbingan dan Konseling, Fakultas Keguruan dan Ilmu Pendidikan, \\ Universitas Borneo Tarakan \\ tricahyonoubt@gmail.com
}

\begin{abstract}
Abstrak
Academic procrastination merupakan sebuah perilaku negatif yang hampir terjadi pada seluruh peserta didik. Academic procrastination merupakan perilaku penghindaran terhadap tugas-tugas akademik dengan alasan adanya aktifitas lain sehingga membuat tugas-tugas utama terabaikan. Gejala academic procrastination sebagian besar ditunjukkan dari beberapa perilaku seperti sering menunda tugas-tugas pribadi, menghindari tanggung jawab akademik dan mementingkan kegiatan lain yang sebenarnya itu hanyalah sebuah bentuk penghindaran terhadap tanggung jawab yang diembannya. Dalam skala yang lebih luas, AP bisa berdampak keputus-asaan, stress dan paranoid terhadap tanggung jawabnya sendiri. Hal itu bisa terjadi karena beberapa faktor. Beberapa penelitian mengenai faktor penyebab AP pada mahasiswa sangat bervariasi. Hal itu disebabkan berbedanya situasi yang melatarbelakangi keadaan pikologis dan sosial mahasiswa. Artinya, faktor penyebab AP pada satu instansi pendidikan tinggi akan berbeda dengan instansi pendidikan tinggi lainnya. Berdasarkan hasil penelitian diketahui bahwa indeks kelulusan mahasiswa yang lulus tepat waktu dibawah 50\%. Pada faktor primer, AP bisa terjadi karena anxiety, time disorganization, poor task approach, stress and fatigue. Selain itu, faktor sekunder yang juga menjadi penyebab AP seperti low discomfort tolerance and pleasure seeking, self-depreciation, environmental disorganization dan lack of assertion.
\end{abstract}

Kata Kunci: Academic Procrastination; Tingkat Kelulusan; Mahasiswa Tingkat Akhir.

\section{PENDAHULUAN}

Perilaku menunda-nunda terhadap tugas atau pekerjaan kerapkali terjadi dalam diri seseorang. Perilaku menunda-nunda atau yang sering disebut "malas" ini muncul bukan secara tiba-tiba. Munculnya gangguan dari luar serta adanya motivasi kesenangan lain menjadi faktor dari tertundanya sebuah tugas atau pekerjaan. Alhasil, tidak sedikit pekerjaan yang harusnya akhirnya tidak dapat terselesaikan akibat waktu yang harusnya digunakan untuk menyelesaikan pekerjaan digunakan untuk hal lain. Pada istilah psikologi, penundaan terhadap tugas atau pekerjaan diatas disebut dengan prokrastinasi. 
Prokrastinasi terjadi pada banyak konteks kehidupan. Pada dunia pendidikan penundaan ini sering dikenal dengan istilah prokartinasi akademik. Prokrastinasi akademik dikenal sebagai perilaku menunda-nunda atau penghindaran akan tugas-tugas akademik. Dalam konteks pendidikan tinggi, tugas-tugas akademik itu bisa sangat beragam. Mulai dari tugas paper/makalah untuk, tugas observasi, tugas menyusun KRS, sampai pengerjaan skripsi/tugas akhir sebagai syarat kelulusan mahasiswa.

AP dipandang sebagai kata yang berkonotasi negatif yakni sejak munculnya revolusi industri hingga saat ini (Oxford English Dictionary dalam Ferari, Johnson, \& McCown, 1995). Sementara itu, menurut Steel (2007) bahwa prokrastinasi merupakan perilaku menunda dengan sengaja kegiatan yang diinginkan walaupun individu mengetahui bahwa perilaku penundaanya dapat menghasilkan dampak buruk. Berdasarkan beberapa pendapat diatas, peneliti simpulkan bahwa prokrastinasi akademik dipahami sebagai perilaku yang dibiasakan atau menjadi kebiasaan (secara disengaja) oleh individu dalam menyikapi tugastugas akademik yang diberikan, sehingga cenderung mengarah pada perilaku yang negatif.

Beberapa hasil penelitian menemukan bahwa faktor internal individu memiliki peran penting penting dalam memengaruhi perilaku prokrastinasi seseorang. Janssen dan Carton (2009) mengusulkan lima hal yang sering dikaitkan dengan tingginya kecenderungan prokrastinasi, yaitu rendahnya kontrol diri (self-control), self-consciousness, self-esteem, dan self-efficacy, serta adanya kecemasan sosial. Hal ini senada dengan apa yang diungkapkan Steel (2007) bahwa prokrastinasi akademik memiliki korelasi negatif yang kuat dengan self-control, artinya jika individu memiliki kontrol diri yang baik maka dirinya akan bisa menghindari prokrastinasi.

Banyak penelitian yang mengutarakan bahwa prokrastinasi akademik sering muncul pada mahasiswa. Catrunada (2008) melakukan penelitian mengenai prokrastinasi dikalangan mahasiswa, dimana hasilnya ditemukan bahwa sebagian besar mahasiswa menganggap bahwa skripsi merupakan tugas yang sulit dan menuntut kemandirian tinggi sehingga membuat banyak mahasiswa dengan self-control rendah cenderung akan menunda-nunda pengerjaan skripsi mereka.

Hal itu dikuatkan oleh penelitian oleh Solomon dan Rothblum (2015) yang menyatakan bahwa prokrastinasi akademik yang paling banyak dilakukan oleh mahasiswa terutama dalam mengerjakan tugas paper laporan, belajar untuk ujian, dan membaca tugas mingguan. Ketiga area tersebut mengindikasikan bahwa tugas ini harus dilihat sebagai sesuatu yang penting. Frekuensi penundaan yang dilakukan oleh mahasiswa memengaruhi performa mereka dalam bidang akademik. Dalam kontek budaya Indonesia, Muhid (2009) dan Ghufron (2003) juga menemukan hal yang sama bahwa bahwa prokrastinasi memiliki korelasi yang signifikan dengan self-control.

Data penelitian diatas mengindikasikan bahwa prokartinasi akademik pada mahasiswa kerap muncul akibat dari lemahnya self-control mahasiswa. Kemandirian belajar (learning autonomy) yang kerap ditekankan kepada mahasiswa membuat mahasiswa harus 
mampu memanajemen dirinya sendiri (self-control). Penundaan yang kerap terjadi itu membuat seringkali menjadi penyebab utama dari tidak terselesaikannya tugas akademik.

Secara implisit, penundaan yang terjadi bukan saja tanpa alasan. Penundaan atas tugas atau pekerjaan tertentu justru seringkali terjadi dengan sengaja atau sukarela atas tujuan tertentu. Hal tersebut dikuatkan oleh pendapat Steel (2010) yang mengatakan bahwa prokrastinasi adalah suatu penundaan sukarela yang dilakukan oleh individu terhadap tugas/pekerjaannya meskipun ia tahu bahwa hal ini akan berdampak buruk pada masa depan. Untuk mengetahui hal itu, peneliti telah melakukan studi pendahuluan untuk mengetahui bentuk-bentuk prokartinasi mahasiswa dalam menyelesaikan skripsi/tugas akhirnya.

Penjelasan diatas sejalan dengan hasil penelitian dari Tangney, Baumeister, dan Boone (2014) menyatakan bahwa self-control memiliki kapasitas besar dalam memberikan perubahan positif pada kehidupan seseorang. Menurut Ray (2011), secara umum self-control yang rendah mengacu pada ketidakmampuan individu menahan diri dalam melakukan sesuatu serta tidak memedulikan konsekuensi jangka panjang. Sebaliknya, individu dengan self-control yang tinggi dapat menahan diri dari hal-hal yang berbahaya dengan mempertimbangkan konsekuensi jangka panjang

Penelusuran secara mendalam mengenai sebab-akibat terjadinya academic procrastination merupakan fokus utama dalam penelitian ini. Penelitian ini akan mengidentifikasi berbagai bentuk academic procrastination pada mahasiswa tingkat akhir Universitas Borneo Tarakan. Target dari penelitian ini adalah ditemukannya pola academic procrastination disorder mulai dari penyebab dasar (grass roots) sampai dampak buruknya (sustained effect) bagi mahasiswa tingkat akhir Universitas Borneo Tarakan. Dengan ditemukannya pola itu, diharapkan para pemangku kebijakan dapat menentukan regulasi yang tepat dalam menanggulangi dampak buruk academic procrastination mahasiswa tingkat akhir.

\section{METODE PENELITIAN}

Penelitian tentang academic procrastination Mahasiswa Tingkat Akhir Universitas Borneo Tarakan mengacu pada desain penelitian kuantitif dengan metode atau pendekatan survey. Pada penelitian ini, academic procrastination (AP) diposisikan sebagai sebuah objek yang akan didiagnosis, dipetakan dan dideskripsikan untuk mendapatkan jawaban dari objek survey yang diteliti. Adapun sasaran dari penelitian ini adalah mahasiswa tingkat akhir yang sedang menempuh skripsi/tugas akhir yang terindikasi mengalami academic procrastination. Total objek survei sejumlah 200 mahasiswa yang sedang menempuh skripsi/tugas akhir yang tersebar di lima fakultas di Universitas Borneo Tarakan.

\section{HASIL DAN PEMBAHASAN}

Penelitian ini akan mengidentifikasi berbagai bentuk academic procrastination pada mahasiswa tingkat akhir Universitas Borneo Tarakan. Target dari penelitian ini adalah ditemukannya pola academic procrastination disorder mulai dari penyebab dasar (grass 
roots) sampai dampak buruknya (sustained effect) bagi mahasiswa tingkat akhir Universitas Borneo Tarakan. Dengan ditemukannya pola itu, diharapkan para pemangku kebijakan dapat menentukan regulasi yang tepat dalam menanggulangi dampak buruk academic procrastination mahasiswa tingkat akhir.

Survei dilakukan pada lima fakultas di Universitas Borneo Tarakan yang sedang menempuh skripsi/tugas akhir. Dari 20 item bentuk Academic Procrastination yang diberikan ke responden, peneliti hanya mengambil enam bentuk prokartinasi yang dipilih lebih dari $60 \%$ responden. Mahasiswa yang tidak memiliki stress management yang bagus akan mengalami gangguan stress ringan akibat tekanan dan tuntutan dari dosen pembimbing skripsi yang berakibat pada gangguan kecemasan. Secara lebih detail hasil prokartinasi mahasiswa berdasarkan studi penelitian ini dapat dilihat dalam grafik berikut.

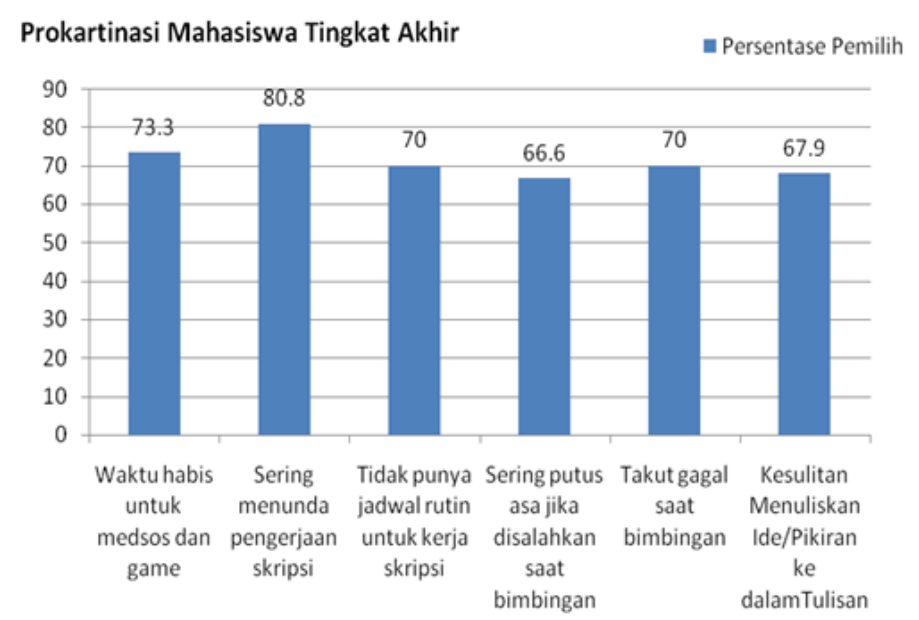

\section{Grafik 1. Persentase Academic Procrastination Mahasiswa Tingkat Akhir}

Berdasarkan studi tersebut, dapat diketahui bahwa Academic Procrastination mahasiswa didominasi oleh hal-hal yang kurang bermanfaat seperti sering menunda pekerjaan skripsi dan menghabiskan waktu untuk mengakses medsos/game (dipilih 90,8\% dan $73,3 \%$ responden). Selanjutnya tidak punya jadwal rutin mengerjakan skripsi (dipilih $70 \%$ responden) dan takut gagal saat bimbingan menjadi alasan mahasiswa tidak menyelesaikan skripsi (dipilih 70\% responden). Selanjutnya, sulit menuliskan ide dalam tulisan dan putus asa menjadi alasan yang relatif dipilih oleh mayoritas mahasiswa (dipilih $67,9 \%$ dan $66,6 \%$ responden).

Data hasil studi tersebut jika dikaji menurut teori yang diungkapkan Ferrari \& Morales (2007) sangatlah cocok. Dimana Ferrari \& Morales mngungkapkan bahwa Academic Procrastination dibagi menjadi 2 jenis. Pertama, functional procrastinasi, yaitu menunda pekerjaan dengan alasan dan tujuan tertentu. Salah satu contohnya ketika seseorang pelajar sengaja menunda pekerjaan diakibatkan untuk menemukan momen tertentu seperti menemukan bahan belajar yang tepat, menunggu waktu yang tepat bertemu pembimbingan 
akademik dan lainnya. Menurut ferrari perilaku penundaan yang disengaja dapat menjadi strategi bagi seseorang untuk memotivasi dirinya sendiri dan bertindak lebih terkontrol, dan orang tersebut dapat melakukan yang terbaik dari pekerjaannya akibat penundaan dalam waktu yang terbatas. Ketika dipertimbangkan dalam konteks ini, penundaan bisa menjadi positif atau negatif.

Kedua, dysfunctional procrastinasi, yaitu menunda pekerjaan tanpa adanya tujuan tertentu, ada dua jenis dysfunctional prokrastinasi antara lain (1) desisional procrastination yaitu kesengajaan menunda pekerjaan atau tugas-tugas untuk menghindari kemungkinan stres, (2) avoidance procrastination yaitu kesengajaan menunda pekerjaan untuk mengurangi beban dalam tugas-tugas yang dimiliki dengan cara mengingkari kesepakatan waktu yang telah diberikan, (3) Behavioral procrastination, yaitu suatu penundaan yang dilakukan sebagai bentuk penghindaran terhadap tugas-tugas yang dirasa tidak menyenangkan dan sulit dikerjakan.

Jika hasil penelitian ini dikaji dari 2 unsur tersebut maka jenis prokastinasi dalam penelitian ini tidak ada yang termasuk kedalam functional procrastination. Semua hasil penelitian ini termasuk kedalam functional procrastination. Artinya, semua jenis prokastinasi dalam penelitian ini adalah prokastinasi yang merugikan dan tidak ada satupun perilaku prokastinasi dalam penelitian ini yang memang secara sadar dilakukan mahasiswa dengan alasan lain yang menguntungkan.

Selain dikaji dari segi funsionalnya, hasil penelitian ini juga dikaji dari segi bentuk prokastinasinya. Menutu Janssen \& Carton (2009) ada beberapa spesifikasi prokrastinasi akademik atau perilaku spesifik, yakni sebagai berikut:

1. perilaku penundaan baik saat memulai maupun menyelesaikan tugas-tugas;

2. perilaku menunda yang dilakukan menghasilkan akibat-akibat yang lebih jauh, seperti keterlambatan mengumpulkan tugas bahkan kegagalan dalam mengerjakan tugas;

3. perilaku menunda yang dilakukan bahkan terhadap tugas-tugas yang dianggap penting bagi individu bersangkutan; dan

4. menunda tugas karena lebih memilih melakukan aktifitas lain yang lebih menyenangkan.

Jika dikaji dari poin pertama yakni perilaku penundaan baik saat memulai maupun menyelesaikan tugas-tugas, hasil dalam penelitian ini terdapat kesesuaian di dua perilaku. Pertama perilaku sering menunda pengerjaan skripsi yang di pilih oleh $80,8 \%$ subjek dan kesulitan menuliskan ide dan pikiran ke dalam skripsi yang dipilih oleh $67,9 \%$ subjek. Jika dikaji dari poin kedua tentang perilaku menunda yang dilakukan menghasilkan akibat-akibat yang lebih jauh, seperti keterlambatan mengumpulkan tugas bahkan kegagalan dalam mengerjakan tugas, maka sesuai dengan hasil penelitian pada item sering putus asa jika disalahkan saat bimbingan yang dipilih oleh $66,6 \%$ dari subjek penelitian dan takut gagal saat bimbingan yang dipilih oleh $70 \%$ subjek penelitian. Berdasarkan kaijan itu disimpulkan bahwa akibat menunda-nunda membuat hasil skripsi tidak maksimal sehingga mahasiswa 
menjadi disalahkan oleh pembimbing sehingga mahasiswa tersebut menjadi putus asa dan takut untuk bimbingan.

Jika dikaji dari poin ketiga yakni perilaku menunda yang dilakukan bahkan terhadap tugas-tugas yang dianggap penting bagi individu bersangkutan, ini mirip dengan poin pertama tadi yakni sering menunda pengerjaan skripsi yang di pilih oleh $80,8 \%$ subjek dan kesulitan menuliskan ide dan pikiran ke dalam skripsi yang dipilih oleh 67,9\% subjek. Jika dikaji dari poin terakhir yakni menunda tugas karena lebih memilih melakukan aktifitas lain yang lebih menyenangkan, poin ini sesuai denga hasil penelitian pada item waktu habis untuk medsos dan game yang dipilih oleh $73,3 \%$ subjek penelitian dan tidak punya jadwal rutin untuk kerja skripsi yang dipilih oleh $70 \%$ subjek penelitian.

Selain faktor tersebut sebenarnya ada faktor lain yang melatar belakanginya. Hal ini juga sesuai dengan hasil penelitian yang tidak dituliskan dalam artikel ini, seperti keinginan bahwa tugas harus sempurna, cemas saat dievaluasi, lingkungan tidak mendukung dan terlanjut banyaknya tugas sehingga mahasiswa tidak tahu mana yang akan dikerjakan dahulu dan tidak tahu bagaimana cara memulainya. Hal itu sesuai dengan apa yang diungkapkan Tice \& Baumeiste (2017) yang menyebutkan bahwa penyebab perilaku prokrastinasi diantaranya sebagai berikut.

1. Adanya pikiran irrasional seperti anggapan bahwa tugas harus diselesaikan dengan sempurna.

2. Adanya kecemasan karena kemampuanya dievaluasi, ketakutan akan kegagalan dan sulit mengambil keputusan atau karena membutuhkan keterampilan orang lain.

3. Malas dan kesulitan mengatur waktu dan tidak menyukai tugasnya.

4. Adanya perasaan tidak suka terhadap punishment dan reward sehingga merasa lebih aman jika tidak melakukan dengan segera karena dapat menghasilkan sesuatu yang tidak maksimal.

5. Adanya faktor lingkungan, yaitu kurangnya pengawasan dari pihak-pihak yang terkait seperti orang tua, guru/dosen dan teman-temannya.

6. Adanya tugas yang menumpuk dan harus segera dikerjakan sehingga penundaan tugas yang satu menyebabkan tugas lain tertunda.

Setelah hasil penelitian diatas dieskplorasi lebih lanjut dan dianalisis lebih dalam perilaku-perilaku academic procrastination itu tidak berdiri sendiri. Namun diantara satu perilaku dengan perilaku lain saling berkaitan satu sama lain. Secara terperinci kaitan antara satu perilaku academic procrastination dan perilaku academic procrastination lain dalam penelitian ini dapat dilihat pada bagan berikut. 


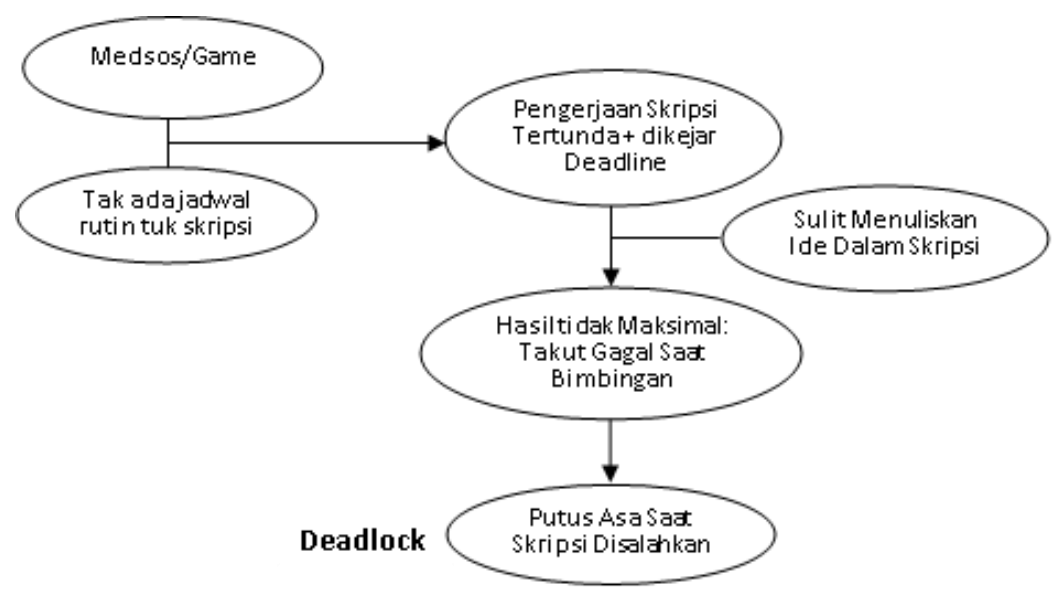

Gambar 1. Kaitan antar Perilaku Academic Procrastination

Berdasarkan gambar diatas diketahui bahwa medsos dan game menjadi hulu dari perilaku masalah. Hal itu semakin diperparah dengan tidak adanya jadwal rutin dalam mengerjakan skripsi. Akibat dari tidak adanya jadwal pengerjaan skripsi membuat pengerjaan skripsi menjadi tertunda, sehingga ketika dealine atau batas waktu pengerjaan skripsi menjelang berakhir mahasiswa akan mengebut pengerjaan skripsi.

Hal tersebut diperparah dengan sulitnya menliskan ide dalam skripsi. Secara psikologis jika seseorang tertekan maka pekerjaan yang mudahkpun akan menjadi sulit. Pengerjaan skripsi yang dikebut tentunya tidak akan menghasilkan tulisan yang maksimal yang berimbas pada ketakutan dalam bimbingan. Ketakutan itu bisa karena takut disalahkan, takut gagal dan bahkan takut untuk bertatap muka dengan pembimbing.

Muara dari ketakutan itu adalah keputusasaan. Mahasiswa yang mempunyai keteguhan diri rendah akan putus as ajika bertubi-tubi disalahkan oleh pembimbing. Hal itu membuat pengerjaan skripsi menjadi buntu atau deadlock. Kebuntuan itu jika dibiarkan akan mengganggu produktifitas dan kreatifitas individu dalam mengembangkan potensi dan keterampilan dirinya. Kelulusan akan tertunda bahkan peluang untuk mengembangkan diri akan berkurang.

Ferrari dan Morales (2007) mengatakan dampak negatif academic procrastination bagi para mahasiswa, yaitu banyaknya waktu yang terbuang tanpa menghasilkan sesuatu yang berguna. Tice dan Baumeister (2017) juga mengatakan bahwa academic procrastination dapat menyebabkan stres dan memberi pengaruh pada disfungsi psikologis individu. Individu yang melakukan prokrastinasi akan menghadapi deadline dan hal ini dapat menjadi tekanan bagi mereka sehingga menimbulkan stres. Jauh sebelumnya Burns, Dittman, Nguyen, \& Mitchelson (2000) serta Wolters (2003) juga telah mengungkapkan hasil dari menunda-nunda bahwa seseorang akan kehilangan waktu, kesehatan yang terganggu, dan harga diri yang rendah. 


\section{SIMPULAN}

Academic procrastination mahasiswa didominasi oleh hal-hal yang kurang bermanfaat seperti sering menunda pekerjaan skripsi dan menghabiskan waktu untuk mengakses medsos/game, tidak punya jadwal rutin mengerjakan skripsi, takut gagal saat bimbingan menjadi alasan mahasiswa tidak menyelesaikan skripsi, sulit menuliskan ide dalam tulisan dan putus asa menjadi alasan yang relatif dipilih oleh mayoritas mahasiswa. Jika diurai lebih luas dan dianalisis lebih dalam, medsos dan game menjadi hulu dari perilaku masalah. Hal itu semakin diperparah dengan tidak adanya jadwal rutin dalam mengerjakan skripsi yang berakibat pengerjaan skripsi menjadi tertunda, sehingga ketika dealine atau batas waktu pengerjaan skripsi menjelang berakhir mahasiswa akan mengebut pengerjaan skripsi.

Sulitnya menuliskan ide dalam skripsi membuat pengerjaan skripsi menajdi tidak maksimal. Secara psikologis jika seseorang tertekan maka pekerjaan yang mudahkpun akan menjadi sulit. Pengerjaan skripsi yang dikebut tentunya tidak akan menghasilkan tulisan yang maksimal yang berimbas pada ketakutan dalam bimbingan. Ketakutan itu bisa karena takut disalahkan, takut gagal dan bahkan takut untuk bertatap muka dengan pembimbing. Muara dari ketakutan itu adalah keputus asaan. Mahasiswa yang mempunyai keteguhan diri rendah akan putus as ajika bertubi-tubi disalahkan oleh pembimbing. Hal itu membuat pengerjaan skripsi menjadi buntu atau deadlock.

\section{DAFTAR PUSTAKA}

Borg, R. \& Gall, M. D. (1983). Educational Reseach.An Introduction. White Plain, New York: Longman, Inc.

Catrunada, L. (2008). Perbedaan kecenderungan prokrastinasi tugas skripsi berdasarkan tipe kepribadian introvert dan ekstrovert (Tesis tidak dipublikasikan). Universitas Gunadarma, Jakarta.

Ferari, J. R., Johnson, J. L., \& McCown, W. (1995). Procrastination and task avoidance: theory, research, and treatment. New York: Plenun Press.

Ferari, J. R., \& Morales, J. F. D. (2007). Perceptions of self-concept and self-presentation by procrastinators: Further Evidence. The Spanish Journal of Psychology, 10 (1), hlm. 91-96.

Ghufron, M. N. (2003). Hubungan kontrol diri dan persepsi remaja terhadap penerapan disiplin orangtua dengan prokrastinasi akademik (Tesis tidak dipublikasikan). Universitas Gadjah Mada, Yogyakarta.

Janssen, T., \& Carton, J. S. (2009). The effects of locus of control and task difficulty on procrastination. The Journal of Genetic Psychology, 160 (4), hlm. 436-452.

Muhid, A. (2009). Hubungan antara self-control dan self-efficacy dengan kecenderungan perilaku prokrastinasi akademik mahasiswa Fakultas Dakwah IAIN Sunan Ampel Surabaya. Jurnal Ilmu Dakwah, 18 (1), hlm. 578. 
Ray, J. V. (2011). Developmental trajectories of self-control: Assessing the stability hypothesis. Disertasi (tidak diterbitkan), University of South Florida, South Florida.

Stake, R. E. (2005). Qualitative Case Studies. In N. K. Denzin \& Y. S. Lincoln (Eds.), The Sage handbook of qualitative research (p. 443-466). Sage Publications Ltd.

Solomon, L. J. \& Rothblum, E. D. (2015). Academic procrastination: Frequency and cognitive-behavioral correlates. Journal of Counseling Psychology, 31, hlm. 503-509.

Steel, P. (2007). The nature of procrastination: A meta analytic and theoretical review of quintessential self regulatory failure. Psychological Bulletin, 133 (1), hlm. 65-94.

Steel, P. (2010). Arousal, avoidant and decisional procrastinators: Do they exist? Journal of Personality and Individual Differences, 48, hlm. 926-934.

Tangney, J. P., Baumeister, R. F., \& Boone, A. L. (2014). High self-control predicts good adjustment, less pathology, better grades, and interpersonal success. Journal of Personality, 72 (2), hlm. 271-322.

Tice, D. M. \& Baumeister, R. F. (2017). Longitudinal study of procrastination, performance, stress, and health: The cost and benefits of dawdling. Journal of Psychological Science, 8 (6), 454-458 
144 | Cahyono - Dampak Negatif Academic ... 